\title{
Elevated nutrients and herbivory negatively affect Dictyota growth dynamics
}

\author{
Tanya N. Ramseyer ${ }^{1,4, *}$, Ana Tronholm ${ }^{2,3}$, Teresa Turner ${ }^{1}$, Marilyn E. Brandt ${ }^{1}$, \\ Tyler B. Smith ${ }^{1}$ \\ ${ }^{1}$ University of the Virgin Islands, USVI 00802, USA \\ ${ }^{2}$ Department of Biological and Environmental Sciences, University of Gothenburg, 41319 Göteborg, Sweden \\ ${ }^{3}$ Gothenburg Global Biodiversity Centre, University of Gothenburg, 41319 Göteborg, Sweden \\ ${ }^{4}$ Present address: Florida Fish and Wildlife Conservation Commission (FWC), South Florida Regional Lab, Marathon, \\ FL 33050, USA
}

\begin{abstract}
Caribbean coral reefs are experiencing a shift to algal dominance at the expense of stony corals. Determining the factors leading to algal phase shifts is crucial for assuring the survival of Caribbean coral reefs. In this study, factors controlling the growth of the abundant brown macroalgae Dictyota spp. were investigated by varying herbivory pressure (caging) and nutrients (fertilizer addition) on coral reefs near St. Thomas (US Virgin Islands). Experiment 1 measured Dictyota heights and percent cover at 3 sites (11-20 $\mathrm{m}$ depth) and showed no growth response to nutrient addition and a weak negative response to herbivory. To confirm results of Experiment 1, a caging and nutrient manipulation (Experiment 2) was conducted at one site (14 m depth) using the dependent variable Dictyota biomass. A strong negative response of growth to nutrient addition was shown, presumably because of nutrient inhibition, and an equally negative response to herbivory (loss of $\sim 50 \%$ biomass over $21 \mathrm{~d}$ ). The inhibitory effect of fertilization on growth was confirmed in a third experiment that showed increasing biomass loss over 4 treatment levels of increasing fertilizer addition (0 [ambient], 5, 10, 20 g). Overall, Dictyota was not nutrient limited at any sites, and was weakly controlled by herbivore populations. Factors responsible for Dictyota abundance on Caribbean reefs may reflect decreased herbivory caused by overfishing and reductions in coral cover and do not appear to be affected by recent changes in nitrogen or phosphorus load. This study reinforces the need for conservation and management of herbivores in coral reef ecosystems, to mitigate the effects from anthropogenic stressors.
\end{abstract}

KEY WORDS: Macroalgae $\cdot$ Dictyota $\cdot$ Herbivory $\cdot$ Nutrients $\cdot$ Coral Reef $\cdot$ Phase shift $\cdot$ Caribbean

\section{INTRODUCTION}

Coral reef ecosystem services contribute greatly to the well-being of millions of people, yet over the past 3 decades they have experienced unprecedented disturbances worldwide, in particular in the Caribbean, leading to a decrease in coral cover along with an increase in algal cover (Mumby et al. 2007, Mumby 2009, Jackson et al. 2014). This 'phase shift' (Bruno et al. 2009) to increased macroalgal cover is associated with coral decline from bleaching events

${ }^{*}$ Corresponding author: Tanya.Ramseyer@MyFWC.com
(Hoegh-Guldberg et al. 2007, Jackson et al. 2014), diseases (Bruno et al. 2007, Brandt et al. 2012), storm disturbances (Gardner et al. 2005), competition with allelopathic (i.e. chemically defended) macroalgal species (Cronin \& Hay 1996, Rasher \& Hay 2010, Rasher et al. 2011), increased water nutrient concentrations (Lapointe 1999), decreased water quality due to human disturbances (McCook 1999), and loss or reductions of herbivores, such as the long-spined sea urchin Diadema antillarum (Philippi, 1845) (Liddell \& Ohlhorst 1986, Lessios 1988), and large herbivores

(1) The authors 2021. Open Access under Creative Commons by Attribution Licence. Use, distribution and reproduction are unrestricted. Authors and original publication must be credited. 
such as parrotfish due to overfishing (Hughes 1994, Jackson et al. 2001, Mumby 2006).

In coral reefs with low fishing pressure and high coral abundance, the force of herbivory is sufficiently strong that herbivores can limit algal biomass accumulation, thus maintaining the abundance of slowgrowing stony corals (Fong et al. 2006, Mumby 2009). Once herbivores are removed or reduced, algae can become highly abundant and overgrow corals. A study by Williams et al. (2001) suggested the amount of substrate occupied by algae on a high coral-cover reef is within the range that can be 'cropped down' by existing populations of herbivores, but as coral cover is lost, the amount of open substrate surpasses that which can be grazed by reef herbivores, resulting in an increase in macroalgal cover. However, herbivory is only one of many factors controlling the abundance of macroalgae on coral reefs. Shifts to macroalgal-dominated states are typically attributed to overfishing of herbivores, leading to excessive growth of macroalgae (Burkepile \& Hay 2006); however, nutrient enrichment also impacts coral reef algae. Increased nutrients such as nitrogen and phosphorus can stimulate rapid algal growth, allowing algae to escape control by herbivores (Bell 1992, Lapointe et al. 1997), resulting in their proliferation. It is important to explore these drivers of shifts to macroalgal-dominated reefs both independently and interdependently.

On shallow coral reefs of the Caribbean, the most abundant species of macroalgae typically belong to the frondose brown algal genus Dictyota J.V. Lamouroux, 1809 (McClanahan \& Muthiga 1998, Littler \& Littler 2000, Jackson et al. 2014). Once established, Dictyota spp. can adversely affect the health of adult and juvenile corals through shading, abrasion, and exposure to secondary chemicals (Lirman 2001, McCook et al. 2001, Beach et al. 2003, Paul et al. 2011, Olsen et al. 2014). The high abundance of Dictyota spp. is often linked to their ability to deter grazers by the production of secondary metabolites (Hay et al. 1987, Hay 1997, Fong \& Paul 2011, Murugan et al. 2012). Relatively few browsing herbivores, or 'browsers', including Acanthurus coeruleus Bloch \& Schneider, 1801, Sparisoma aurofrenatum (Valenciennes, 1840), and Kyphosus spp., predominantly consume established fronds of Dictyota spp. (Dell et al. 2020). Moreover, in Dictyota species, as in other dictyotalean species, reproduction occurs almost entirely by means of sporangia (asexual; King \& Farrant 1987, Womersley 1987, Tronholm et al. 2008, 2010a). Thalli fragmentation and re-attachment can also contribute to population expansion and may be caused by fish grazing, storm disturbances, and other natural processes (Vroom et al. 2005, Herren et al. 2006). The growth of Dictyota spp. is nutrient-limited in some areas (Beach et al. 2006), and Dictyota spp. are susceptible to changes in additional physical variables, such as temperature and light availability (Beach et al. 2006, Renken et al. 2010); however, the specific factors and complex interactions controlling the dynamics of Dictyota spp. growth on Caribbean coral reefs remain largely unknown.

Macroalgal cover has been increasing on reefs of the US Virgin Islands (USVI) and the wider Caribbean since the 1970s (Bruno et al. 2009). The shallow nearshore coral reefs of the USVI were noted as being devoid of macroalgae prior to the 1970s (Mathieson et al. 1971, Gladfelter et al. 1977). Macroalgae were studied as part of the Tektite undersea habitat project at Lameshur Bay in St. John at the Virgin Islands National Park in the early 1970s, and it was noted that '[i]n most cases the algae were restricted to cracks and crevices and they were diminutive in size' (Mathieson et al. 1971, p. 243) and macroalgae with large thalli were restricted to off-reef zones in soft sediments where herbivory was reduced (Earle 1972). Prior to 1977, at Buck Island National Park in St. Croix, macroalgal cover was less than $20 \%$ (Gladfelter et al. 1977). Macroalgal cover in Lameshur Bay was less than $10 \%$ as late as Hurricane Hugo in 1989 (Rogers \& Miller 2006, Edmunds 2013). Between the 1980s and 1990s, macroalgal cover, and Dictyota spp. cover in particular, increased markedly in Lameshur Bay and the surrounding USVI waters. Edmunds (2019) indicated a 4- to 8-fold increase in macroalgal cover over a $28 \mathrm{yr}$ period ending in July 2017. At 2 sites (Yawzi and Tektite), mean macroalgal cover was $30.3 \%$ between 1999 and 2017, with mean Dictyota spp. cover of $12.3 \%$ (National Park Service South Florida and Caribbean Monitoring Network unpubl. data). By 2016, high coverage of Dictyota spp. on shallow reefs of the USVI was ubiquitous, with 23 shallow monitoring locations $(<25 \mathrm{~m}$ depth) showing a mean \pm SD Dictyota cover of $19.0 \pm 10.9 \%$ (range: $1.5-35.9 \%$ ), within an overall fleshy macroalgal cover of $36.9 \pm 17.8 \%$ (range: $2.3-67.2 \%$ ) (Smith et al. 2016). Thus, the shallow coral reefs of the USVI have undergone a shift to high macroalgal abundance, largely driven by Dictyota spp. (Fig. S1 in the Supplement at www.int-res.com/articles/suppl/ m671p081_supp.pdf). However, even in established populations, dramatic variations of Dictyota spp. cover can occur over periods of months (Fig. S1).

Part of the reason for the increase in macroalgal abundance in general, and Dictyota spp. in particu- 
lar, has likely been a decrease of reef herbivore populations in the Caribbean and USVI over the last 50 yr (Bruno et al. 2009, Kadison et al. 2017). In addition to the well-described collapse of Diadema antillarum populations, reef fishes are showing what may be historically low biomass. Average parrotfish biomass values in the USVI have been extremely low since the 1950s, hovering around 5-10 $\mathrm{g} \mathrm{m}^{-2}$ (Jackson et al. 2014) likely because of overfishing (Friedlander $\&$ Beets 2008). For context, the biomass average in St. Thomas, USVI (since 1998; $11.4 \mathrm{~g} \mathrm{~m}^{-2}$ ) is similar to other low-nutrient areas subject to long-term overfishing such as Belize $\left(7.1 \mathrm{~g} \mathrm{~m}^{-2}\right)$, but very different from less fished areas like Costa Rica (39.8 $\mathrm{g} \mathrm{m}^{-2}$; Jackson et al. 2014, Shantz et al. 2020). The contribution of rising nutrients to the increase in macroalgae is less clear; however, since even remote areas away from localized anthropogenic nutrient inputs have seen high abundance of macroalgae and lack of effect from experimentally elevated nutrients, it seems that any eutrophication effect may be regional rather than localized (McClanahan \& Muthiga 1998, McClanahan et al. 2004).

To date, it is still not clear which factors are most important for promoting and inhibiting natural populations of Dictyota spp. at a reef scale. In this study, we hypothesized that nutrient addition and herbivore reduction would positively influence Dictyota spp. growth. Three experiments were conducted in series to determine the importance of nutrients and herbivory as factors influencing the abundance of Dictyota spp., specifically to test whether nutrient addition and herbivore reduction (1) facilitated thallus growth measured as height and percent cover and (2) increased biomass, and to test (3) the level at which nutrient addition, exclusively, influenced Dictyota spp. biomass.

\section{MATERIALS AND METHODS}

\subsection{Study sites, specimen collection, and characterization}

This study took place at 3 coral reef sites on the southern shelf of St. Thomas, USVI (Fig. 1). Black Point is a shallow site $(9-11 \mathrm{~m})$, nearshore $(0.07 \mathrm{~km}$ from the mainland of St. Thomas), dominated by weak currents, and is sheltered from high water movement and wind by the nearby airport runway structure and surrounding bays. Flat Cay is a deeper site $(12-15 \mathrm{~m}) 1.35 \mathrm{~km}$ from the mainland, but near a small uninhabited cay to the east that protects the reef from oceanic swell. Seahorse Cottage Shoal (hereafter referred to as Seahorse) is the deepest site (20-21 m), $0.85 \mathrm{~km}$ from the mainland, and is largely buffered from anthropogenic run-off (Fig. 1). These sites do not differ greatly in measured mean physical or biological characteristics, except for differences in depth and distance from shore (Fig. 1; Smith et al.

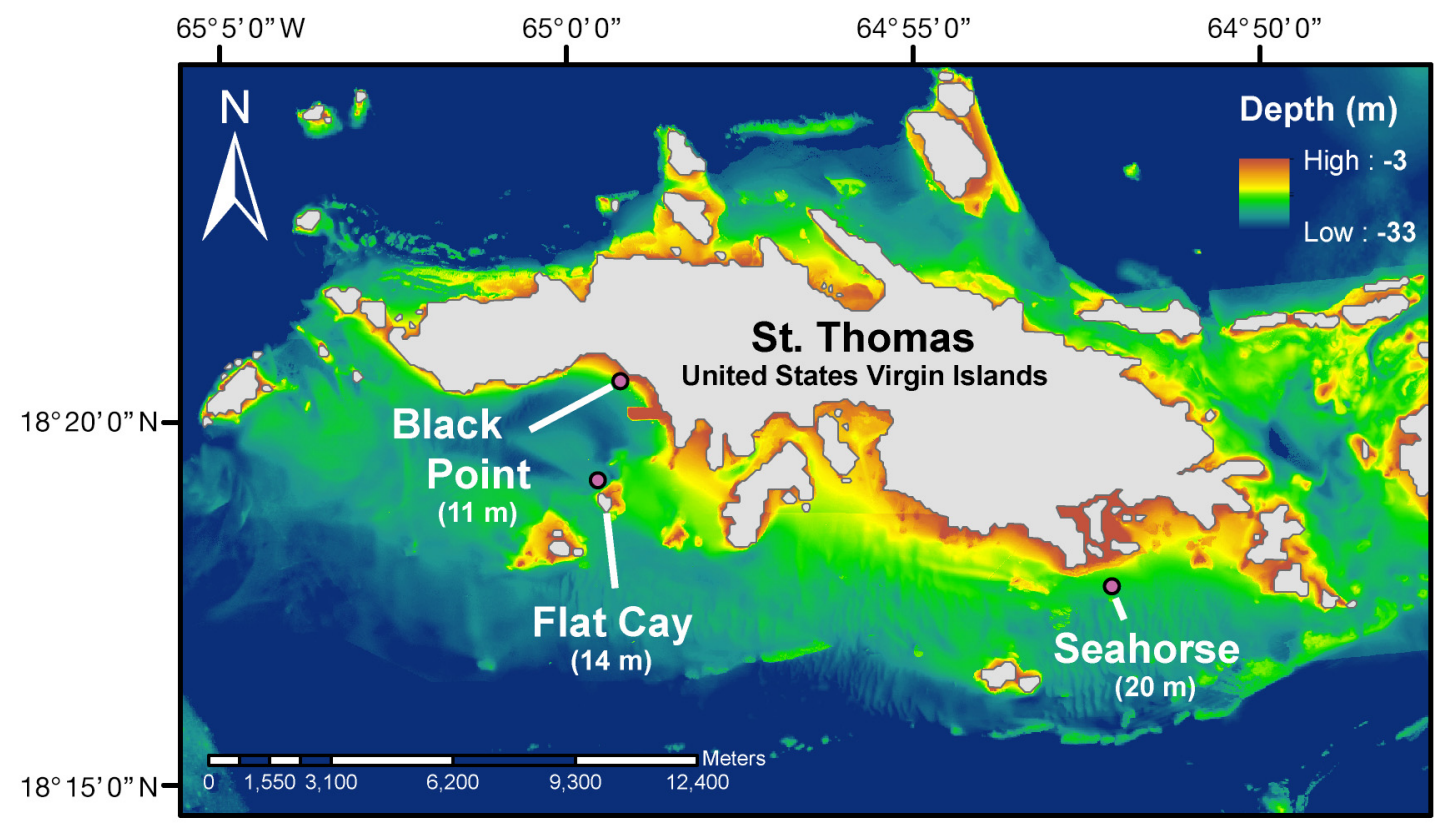

Fig. 1. Study sites and their mean depths in St. Thomas, United States Virgin Islands. Background bathymetry provided by airborne light detection and ranging (Fredericks et al. 2015, Wilson et al. 2019) 
2008). These sites were chosen largely because they have been used as part of long-term, high-frequency data collection efforts of the Territorial Coral Reef Monitoring Program and provide a wealth of ancillary data (Table 1). Fleshy macroalgae and epilithic algae comprise the largest share of benthic cover at the research sites (Table 1; Fig. S1; Smith et al. 2016). Coral cover ranged from 15 to $18 \%$ across all 3 sites, mostly dominated by Orbicella spp. Benthic cover values were calculated from video sampling of $6-$ $10 \mathrm{~m}$ long transects following standard methodologies (Rogers \& Miller 2001, Smith et al. 2008).

The nutrient environment of the study sites can be considered generally low, as dissolved nutrients were often below or near method detection limits, with nutrients elevated in occasional site-specific and regional pulses (Table 1; Fig. S2; Ennis et al. 2016, Smith et al. 2016). In addition, phytoplankton abundance measured as free-water chlorophyll concentration, an indirect and time-integrated estimate of excess nutrients around tropical reefs, was below a value of $0.5 \mu \mathrm{g} \mathrm{l}^{-1}$, which is considered indicative of nutrient enrichment on the Great Barrier Reef, Australia (Furnas et al. 2005): Black Point $=0.44 \pm 0.32 \mu \mathrm{g}$ $\mathrm{l}^{-1}(\mathrm{SD}), \mathrm{n}=49$; Flat Cay $=0.35 \pm 0.18 \mu \mathrm{g} \mathrm{l}^{-1}, \mathrm{n}=53$; and Seahorse $=0.28 \pm 0.19 \mu \mathrm{g} \mathrm{l}^{-1}, \mathrm{n}=52$. Values were taken from monthly to quarterly sonde casts between 2008 and 2015 of a Wetlabs EcoFLNT fluorometer directly over sampling sites and extracted from the deepest meter of the cast closest to the seafloor.

All 3 sites follow similar herbivore community patterns, with a majority of the total species biomass consisting of fish of the genus Sparisoma, followed by
Scarus and Acanthurus (Table 1). A macroalgal browser observed in low abundance was blue tang A. coeruleus, whereas chub (Kyphosis spp.) were not observed (Smith et al. 2016, Dell et al. 2020). Black Point and Flat Cay had low herbivorous fish biomass $\left(<15 \mathrm{~g} \mathrm{~m}^{-2}\right)$, representative of heavily fished sites in the Caribbean, whereas Seahorse had higher biomass $\left(31.8 \mathrm{~g} \mathrm{~m}^{-2}\right)$, more similar to high biomass sites (Jackson et al. 2014, Shantz et al. 2020). Additionally, black long-spined sea urchins Diadema antillarum were rarely spotted at any of the study sites in longterm data (densities $<1$ ind. $100 \mathrm{~m}^{-2}$; Smith et al. 2016); therefore, it can be assumed that they did not contribute to herbivory during our study. Visual fish census methodology at fixed sites followed standard methods (Brock 1982) and consisted of single divers performing 10 timed $(\sim 15 \mathrm{~min}) 30 \times 2 \mathrm{~m}$ belt transects to assess fish abundance and size, as described by Kadison et al. (2017).

Dictyota species are often difficult to identify mainly due to the high morphological plasticity and a lack of distinctive defining features (Tronholm et al. 2010b, 2013), but they are fairly recognizable in the field at the genus level. In this study, we targeted Dictyota populations as morphologically similar as possible, with specimens exhibiting large (up to $\sim 10 \mathrm{~cm}$ thallus length), upright growth form, supple texture, and brown-yellowish/greenish (sometimes iridescent) thalli (4-15 $\mathrm{mm}$ thallus width). The mixed assemblages of Dictyota species are the basis for the experiments conducted in this study.

In order to further confirm the identity of the Dictyota populations under study, representative

Table 1. Site characterization summary table. Generally low nutrient concentrations are shown across all sites (summary from data shown in Fig. S2 in the Supplement). The benthic cover (2008-2016) is dominated by fleshy macroalgae and largely driven by Dictyota. Mean fish biomass, calculated in 2016 only, observed at our 3 study sites includes total herbivores and species known to consume Dictyota (Dell et al. 2020): stoplight parrotfish Sparisoma viride, redband parrotfish $S$. aurofrenatum, and blue tang Acanthurus coeruleus. Table adapted from Territorial Coral Reef Monitoring Program 2008-2016 data (Smith et al. 2016)

\begin{tabular}{|llccc|}
\hline & & Black Point & Flat Cay & Seahorse \\
\hline Nutrient concentrations $(\mu \mathrm{M} \pm \mathrm{SE})$ & Nitrate + nitrite & $0.32 \pm 0.16$ & $0.29 \pm 0.1$ & $0.36 \pm 0.27$ \\
& Phosphorus & $0.08 \pm 0.16$ & $0.05 \pm 0.04$ & $0.07 \pm 0.13$ \\
& Ammonia & $0.53 \pm 0.27$ & $0.48 \pm 0.28$ & $0.56 \pm 0.38$ \\
Benthic cover $(\% \pm \mathrm{SE})$ & Coral & $16.57 \pm 0.22$ & $18.84 \pm 0.19$ & $15.74 \pm 0.20$ \\
& Fleshy macroalgae & $30.23 \pm 1.22$ & $38.20 \pm 1.24$ & $52.86 \pm 1.29$ \\
& Dictyota & $26.36 \pm 1.17$ & $24.65 \pm 1.38$ & $26.16 \pm 1.53$ \\
& Lobophora & $0.09 \pm 0.05$ & $7.92 \pm 0.71$ & $20.49 \pm 1.18$ \\
Herbivorous fish biomass & Total herbivores & $11.6 \pm 7.7$ & $14.7 \pm 12.1$ & $31.8 \pm 27.4$ \\
$\left(\mathrm{~g} \mathrm{~m}{ }^{-2} \pm \mathrm{SD}\right)$ & A. coeruleus & $0.7 \pm 0.5$ & $1.1 \pm 1.5$ & $3.6 \pm 9.5$ \\
& S. aurofrenatum & $1.7 \pm 2.5$ & $2.3 \pm 2.6$ & $11.7 \pm 19.1$ \\
& S. viride & $2.9 \pm 6.4$ & $4.5 \pm 8.4$ & $7.3 \pm 10.6$ \\
\hline
\end{tabular}


specimens were morphologically and genetically screened in the lab. To this end, specimens were collected from all 3 sites and preserved in silica gel and pressed on herbarium sheets. Total genomic DNA was extracted using the DNeasy PowerPlant Pro Kit (Qiagen), and subsequently purified and amplified following Tronholm et al. (2010b). Plastid-encoded PSII reaction center protein D1 ( $p s b \mathrm{~A})$, mitochondrialencoded NADH dehydrogenase subunit 1 (nad1), and partial nuclear large subunit ribosomal DNA were amplified and sequenced. DNA results confirmed that D. bartayresiana J.V. Lamouroux, 1809 and Canistrocarpus cervicornis (Kützing) De Paula \& De Clerc, 2006 (formerly Dictyota cervicornis) are likely among the most abundant species at the sites in this study. These species can easily be misidentified due to similarities in morphology. The basal parts of the thalli of $C$. cervicornis resemble $D$. bartayresiana, especially when $C$. cervicornis specimens are young and the axes are not fully developed. However, for the purpose of this study, the mixed assemblages of species of the closely related genera Dictyota and Canistrocarpus will be referred to as Dictyota sensu lato, hereafter called Dictyota.

\subsection{Experimental design}

Three manipulative experiments were conducted in this study: 2 experiments were conducted to determine whether herbivore reduction and nutrient addition control the dynamics of Dictyota growth, measured as thallus height, percent cover, and biomass. A third experiment assessed the effect of nutrient addition on the growth of ungrazed Dictyota biomass. This study only considered herbivory from macroherbivores (e.g. parrotfish) and assumed a low level by micro-herbivores (e.g. amphipods; Carpenter 1986).

\subsubsection{Expt 1: Effect of nutrients and herbivory on Dictyota height and cover}

Expt 1 tested whether herbivore reduction and nutrient addition control the dynamics of Dictyota growth, measured as thallus height and percent cover. The experiment was conducted from 9 September 2016 to 19 January 2017 (133 d). The experiment was designed as a 2-way factorial experiment to test the effects of herbivore reduction and nutrient addition. At each study site and at similar depths within a site, 46 circular plots (including controls) of $20 \mathrm{~cm}$ in diameter $\left(\right.$ area $\left.=254.5 \mathrm{~cm}^{2}\right)$ containing nat- urally occurring patches of Dictyota were targeted. Plots were haphazardly selected and spaced a minimum of $1 \mathrm{~m}$ apart. Each plot was marked with 3 galvanized masonry nails driven in a line along the plot diameter (top, center, bottom) into the reef substrate (Fig. S3A in the Supplement). These nails designated 2 equal semicircles that were treated separately as described below. Herbivory was manipulated with 2 levels: caged (full herbivore reduction) and uncaged (no herbivore exclusion); and nutrient content was manipulated with 2 levels: enriched (with nutrient addition) and ambient (without nutrient addition). Cylindrical galvanized metal cages, $1 \mathrm{~cm} \times 1 \mathrm{~cm}$ square mesh, $20 \mathrm{~cm}$ diameter, and $25 \mathrm{~cm}$ tall (volume $\left.[\mathrm{V}]=7850 \mathrm{~cm}^{3}\right)$, were used to exclude medium to large-bodied herbivores. Each cage had flanges that were nailed to the benthic substrate to prevent herbivore entry and secure the cage (Fig. S3B). Uncaged areas were marked with masonry nails and flat squares of galvanized wire mesh that were used to identify the plot and to support nutrient diffusers in the nutrient-enriched treatments.

A commonly used plant fertilizer, Osmocote SmartRelease (Sierra Chemical; 19N-6P-12K; hereafter Osmocote), was used to simulate elevated nutrient levels (Worm et al. 2000, Littler et al. 2006a,b, Zaneveld et al. 2016). This type of fertilizer was chosen due to its high nitrogen ratio and to avoid interference with micronutrients. Based on results from a pilot study, each enriched treatment received $40 \mathrm{~g}$ of Osmocote plant fertilizer contained in 2 centrifuge tubes (50 ml volume) with $\sim 35$ small diffusion holes drilled at $\sim 1 \mathrm{~cm}$ intervals (as shown in Fig. S3C). The vials were cable-tied to opposite sides of each cage interior for caged-enriched treatments or were wrapped in wire mesh for uncaged-enriched treatments. Caged-ambient and uncaged-ambient treatments did not receive nutrient addition.

Partial cages were used as cage controls, allowing the effects of shading and water flow reduction to be measured. Partial cages were constructed with the same dimensions as the full cages but included a $15 \times$ $15 \mathrm{~cm}$ hole on one side of the cylinder to allow herbivores to enter and exit. Replicates were placed on the reef haphazardly a minimum of $1 \mathrm{~m}$ apart to reduce cross-contamination with nutrients. Ten replicates for each of the 4 treatments, and 6 replicates for the partially caged plots (cage controls) were used at each site. To reduce effects of fouling and negative effects of light and water flow, cages were replaced with freshly cleaned cages monthly. Fouling was minimal during the month-long deployment. Osmocote plant fertilizer was also replaced monthly. 
Dictyota thallus heights were measured by visually determining the 3 tallest thalli in each patch, gently laying each thallus vertically along a ruler, and measuring to the nearest millimeter. The 3 thallus heights were averaged per semicircle (patch). To determine how Dictyota percent benthic cover responded to treatments, photographs of every plot were taken each month, using Canon G12 or GX1 cameras with Ikelite underwater housings. The photographs of each plot were uploaded into the Coral Point Count Program with Excel Extensions (CPCe; Kohler \& Gill 2006), and 40 random points were overlaid onto the photograph of each plot (20 points per semicircle). Benthic characteristics were then identified underneath each point. The average percent cover of Dictyota was calculated per semicircle. Other algal taxa such as Lobophora variegata and Halimeda spp. were observed in the treatment plots in minor abundance. Dictyota grew mostly epiphytically on these algae and the percent cover analyses only accounted for the top layer of macroalgae. Therefore, we considered that changes in Dictyota abundance were driven by the direct response to changes in herbivory and nutrients and not competition with other algal taxa.

The left and right semicircles of the plots were manipulated differently across the course of the experiment (Fig. S3A). Since the cover of Dictyota was high at the study sites, we hypothesized that the algae were possibly at maximum abundance and therefore would not be responsive to treatments aimed at increasing their growth. To test this hypothesis, the left semicircle of the plot was left untrimmed, and the right was trimmed back to near substrate height to encourage regrowth. After recording monthly height measurements in each sampling period, divers weeded thalli with thumb and forefinger in the trimmed plots to produce a Dictyota mat at an approximate height of $1 \mathrm{~cm}$.

All statistical analyses were performed in the R statistical package v. 3.3, RStudio v. 1.0.136 (R Core Team 2013), and JMP ${ }^{\circledR}$ v. 13 (SAS Institute). Dictyota height data were transformed using a natural log +1 transformation to meet the assumptions of the ANOVA. To test for significant differences in mean Dictyota heights between and among treatments and sites over time, a 3-way repeated measures ANOVA was used with time (month) as the repeated measure and non-independent factor. Percent cover data were transformed using an angular transformation (arcsine square root) to meet the assumptions of the ANOVA. The untrimmed and trimmed semicircle experiments were not tested for differences directly because of loss of statistical power but were compared by visual inspection of graphical results.

\subsubsection{Expt 2: Effect of nutrients and herbivory on Dictyota biomass}

A second experiment was conducted to test the hypothesis that herbivore reduction and nutrient addition contributed to the growth of Dictyota biomass using similar experimental design and treatments as in Expt 1. Biomass was used because of unexpected results in Expt 1 (negative effects of nutrient addition), and this measure was thought to be more sensitive than percent cover to manipulations of nutrients and herbivory. Because the purpose of the second experiment was to confirm the results of the first experiment and not to test broad spatial patterns, it was only conducted at Flat Cay for a duration of 21 d (31 January to 20 February 2017).

During this second experiment, smaller, fully enclosed herbivore reduction cages were made from the same galvanized metal mesh $(15 \mathrm{~cm}$ diameter $\times$ $15 \mathrm{~cm}$ tall; $\mathrm{V}=\sim 3000 \mathrm{~cm}^{3}$ ) for caged-enriched and caged-ambient treatments. Nutrients were elevated with $20 \mathrm{~g}$ of Osmocote plant fertilizer contained in one $50 \mathrm{ml}$ centrifuge tube per plot, with small holes drilled in the side for diffusion (Fig. S3C) in enriched treatments. This fertilizer amount $(20 \mathrm{~g})$ was used to ensure that Dictyota would be released from nitrogen and phosphorus nutrient limitation and would respond to nutrient addition. A lesser amount of fertilizer was used in Expt 2 (compared to $40 \mathrm{~g}$ in Expt 1) because of the proximity of the fertilizer to the algae.

To set up the experimental units, Dictyota thalli bundles were collected from Flat Cay and brought back to the lab (an ocean distance of $3.4 \mathrm{~km}$ ) where they were kept in a flow-through water table. On the same day, bundles of Dictyota were gently spun in a salad spinner for $\sim 1$ min to remove excess water and weighed (Thacker et al. 2001). Each bundle was wet weighed to $5.00 \mathrm{~g}$ and placed into a tray of seawater before being transferred to a water table. In the water table, each bundle was attached to wire mesh for each treatment using small cable ties. Each replicate $(\mathrm{n}=10)$ was installed haphazardly on the reef, 1-2 $\mathrm{m}$ apart. After $21 \mathrm{~d}$, the bundles of Dictyota were collected, re-spun for $\sim 1 \mathrm{~min}$, and re-weighed for a final biomass measurement. The bundles attached to wire mesh were transported to and from the reef in 2 large plastic bins with holes drilled in the sides. If any breakage occurred, it was likely to be equal across treatments; however, care was taken to avoid break- 
age of thalli during all steps. Treatments in Expt 2 were identical to Expt 1 but differed in cage size and fertilizer amount.

The biomass data were analyzed as percent change in Dictyota biomass $\left(\left(y_{2}-y_{1}\right) / y_{1} \times 100\right)$ and were log transformed to meet the assumptions of the ANOVA. To explore differences in mean Dictyota biomass between and among herbivore reduction and nutrient addition treatments, a 2-way ANOVA was used. To test partially caged treatments against uncaged-ambient treatments for caging effects on biomass results, a 1-way ANOVA was used resulting in no significant difference between the 2 treatments $(p=0.983)$.

\subsubsection{Expt 3: Effect of increasing nutrients on Dictyota biomass}

The results of Expt 2 suggested that high concentrations of nutrient addition inhibited Dictyota growth. Therefore, to understand the contribution of nutrient addition to algal growth and to control for potential cage-material interactions with nutrients, we conducted a third experiment, which examined Dictyota biomass changes across 4 nutrient levels in herbivore reduction (caged) conditions over $21 \mathrm{~d}$. Plastic mesh cages $\left(15 \mathrm{~cm}\right.$ diameter $\times 20 \mathrm{~cm}$ tall; $\mathrm{V}=\sim 4000 \mathrm{~cm}^{3}$ ) were used to allow Dictyota biomass to be measured without any possible chemical inhibitory effects of galvanized metal mesh (Fig. S3D). Based on the results from Expts 1 and 2, we hypothesized that Dictyota biomass would be negatively correlated to increasing levels of fertilizer.

Four levels of Osmocote plant fertilizer were used as a treatment to explore the effect of increasing nutrient supply on the change in Dictyota biomass. Plant fertilizer at concentrations of $0 \mathrm{~g}$ (empty plastic tube, ambient), 5, 10, and $20 \mathrm{~g}$ were contained in one $50 \mathrm{ml}$ centrifuge tube per plot (Fig. S3D) with small holes drilled to allow diffusion. New, empty centrifuge tubes without diffusion holes were used as ambient nutrient controls. Each treatment level had 4 replicates; however, 2 experimental plots with the $0 \mathrm{~g}$ treatment level could not be relocated $(\mathrm{n}=2)$. Dictyota bundles were initially collected from Flat Cay and treated for weighing as in Expt 2. They were then placed on the reef for $21 \mathrm{~d}$ from 26 April to 17 May 2017. Finally, the bundles were collected, respun for $\sim 1$ min, and re-weighed.

The biomass data were analyzed as percent change in Dictyota biomass as above. To explore differences in percent change in Dictyota biomass between and among 4 levels of plant fertilizer, a 1way ANOVA was used. Differences between the fertilizer concentrations and period (initial and final) were statistically analyzed using a 2-way ANOVA. A 1-way ANOVA was used to compare the ambient control treatment against the $0 \mathrm{~g}$ treatment.

\subsection{Water nutrient analysis}

To ensure the efficacy of nutrient addition, water samples were collected during Expt 3. A total of 20 samples were taken before $(n=10)$ and after $(n=10)$ the $21 \mathrm{~d}$ experiment. Per treatment, 2 or 3 samples were taken. Water samples $(125 \mathrm{ml})$ were collected in acid-washed Nalgene bottles or new $50 \mathrm{ml}$ Falcon conical centrifuge tubes. Empty bottles or vials were opened approximately $5 \mathrm{~cm}$ from the fertilizer, over the Dictyota spp. patch. After collection, samples were filtered with $33 \mathrm{~mm}$ diameter MF-Millipore membranes $(0.22 \mu \mathrm{m})$ and $60 \mathrm{ml}$ acid-washed syringes. Filtered samples were kept on ice until they could be stored at $-20^{\circ} \mathrm{C}$ in the lab. Each sample was analyzed for nitrites, nitrates + nitrites, orthophosphates, and ammonium using an Astoria-Pacific Auto-analyzer System for Water and Wastewater analysis. Nitrates + nitrites and ammonium are the only parameters reported because nitrite and orthophosphate levels were below the detection limits.

\section{RESULTS}

\subsection{Expt 1: Effect of nutrients and herbivory on Dictyota height and cover}

Growth of Dictyota untrimmed thalli was significantly affected by site, herbivore reduction, and nutrient addition. There was a significant interactive effect of month $\times$ herbivore reduction $\times$ nutrient addition (Table 2). In general, uncaged plots open to herbivory showed reductions in Dictyota height relative to all other treatment levels, but this difference became less apparent in the final month of the experiment (January; Fig. 2). Further, caged-enriched plots showed a general decline in height relative to unenriched treatment levels over each successive period. The deeper site, Seahorse, had lower algal heights than either Black Point or Flat Cay, except for open, enriched treatments, which were low in height across all sites.

Regrowth of Dictyota thalli in the trimmed patches showed an effect of site, herbivore reduction, and 
Table 2. Results of a 3-way factorial repeated measures ANOVA on Dictyota thallus height in untrimmed and trimmed patches in Expt 1. Factors are herbivore reduction ('herbivory'), nutrient addition ('nutrients'), and site. Significant $p$-values ( $p<0.05$ ) are shown in bold

\begin{tabular}{|c|c|c|c|c|c|c|}
\hline \multirow{2}{*}{ Treatment } & \multirow[b]{2}{*}{$\mathrm{df}$} & - Untrimmed & \multirow[b]{2}{*}{$\mathrm{p}$} & \multirow[b]{2}{*}{$\mathrm{df}$} & \multirow{2}{*}{$\begin{array}{c}\text { Trimmed } \\
F \text { (approx. or exact) }\end{array}$} & \multirow[b]{2}{*}{$\mathrm{p}$} \\
\hline & & $F$ (approx. or exact) & & & & \\
\hline Month & 1 & 0.274 & 0.601 & 1 & 1.244 & 0.265 \\
\hline Site & 2 & 9.734 & $<0.0001$ & 2 & 10.333 & $<0.0001$ \\
\hline Herbivory & 1 & 11.884 & $<0.0001$ & 1 & 31.380 & $<0.0001$ \\
\hline Nutrients & 1 & 16.032 & $<0.0001$ & 1 & 29.043 & $<0.0001$ \\
\hline Month $\times$ Site & 2 & 0.640 & 0.528 & 2 & 0.050 & 0.952 \\
\hline Month $\times$ Herbivory & 1 & 4.461 & 0.035 & 1 & 0.479 & 0.489 \\
\hline Month $\times$ Nutrients & 1 & 0.321 & 0.571 & 1 & 0.317 & 0.574 \\
\hline Site $\times$ Herbivory & 2 & 1.610 & 0.201 & 2 & 2.002 & 0.136 \\
\hline Site $\times$ Nutrients & 2 & 1.105 & 0.332 & 2 & 2.658 & 0.071 \\
\hline Herbivory $\times$ Nutrients & 1 & 4.133 & 0.043 & 1 & 0.457 & 0.499 \\
\hline Month $\times$ Site $\times$ Herbivory & 2 & 1.881 & 0.154 & 2 & 0.631 & 0.533 \\
\hline Month $\times$ Site $\times$ Nutrients & 2 & 0.221 & 0.801 & 2 & 0.507 & 0.603 \\
\hline Month $\times$ Herbivory $\times$ Nutrients & 1 & 5.232 & 0.023 & 1 & 2.891 & 0.089 \\
\hline Site $\times$ Herbivory $\times$ Nutrients & 2 & 0.514 & 0.599 & 2 & 1.293 & 0.276 \\
\hline Month $\times$ Site $\times$ Herbivory $\times$ Nutrients & 2 & 0.501 & 0.606 & 2 & 0.510 & 0.601 \\
\hline
\end{tabular}

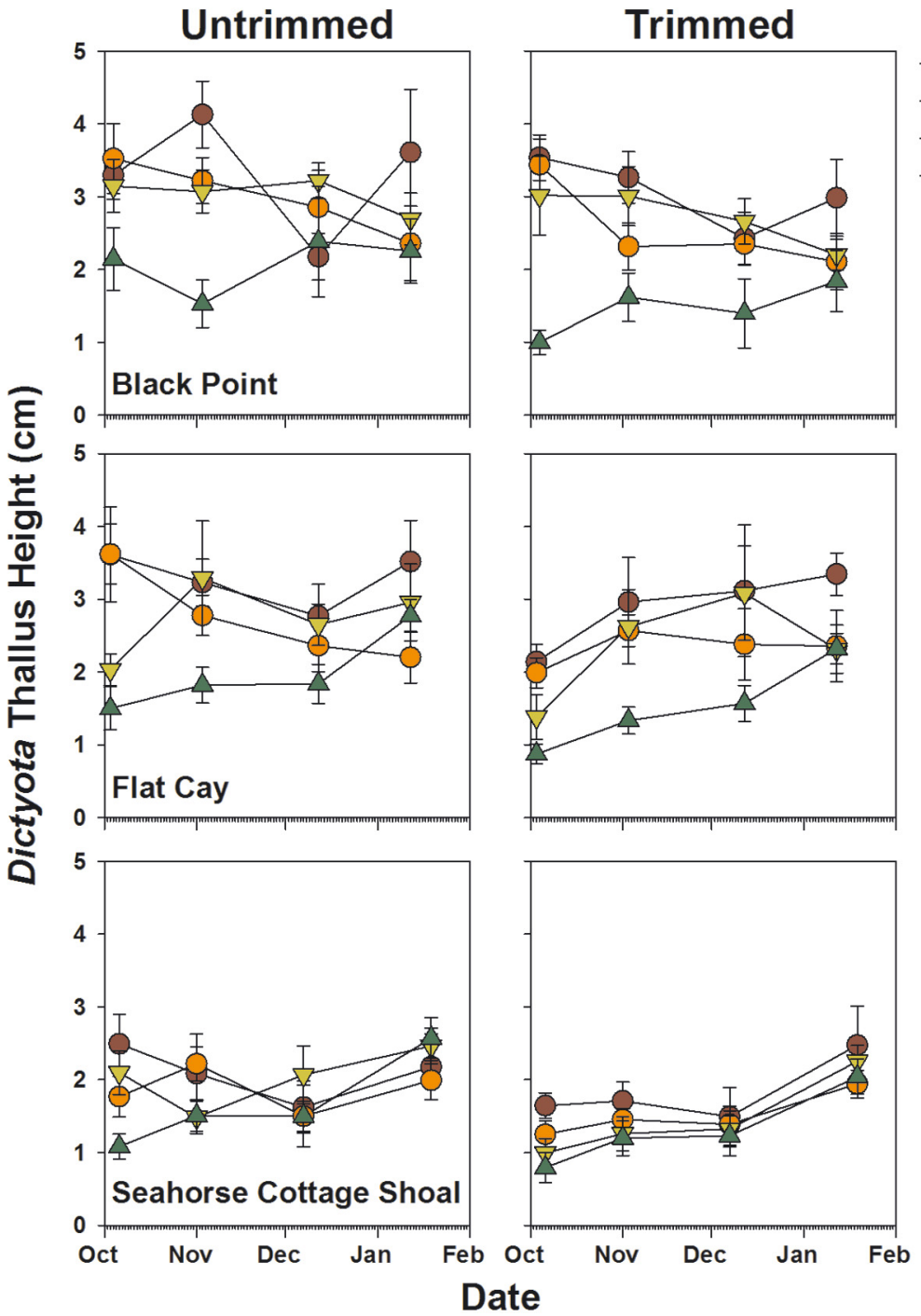

Fig. 2. Expt 1 mean Dictyota heights $(\mathrm{cm}) \pm$ SE for untrimmed and trimmed patches at 3 sites, from October 2016 to January 2017. Ten replicates of each treatment were measured at each site. 'Caged - Ambient' treatments were protected from herbivory and not treated with fertilizer; 'Caged - Enriched': protected from herbivory and treated with $40 \mathrm{~g}$ of fertilizer; 'Uncaged Ambient': exposed to herbivory and not treated with fertilizer; 'Uncaged - Enriched': exposed to herbivory and treated with $40 \mathrm{~g}$ of fertilizer 
nutrient addition, separately, on Dictyota thallus heights, with no significant interactions (Table 2). In general, herbivore reduction plots and ambient nutrient plots showed slightly higher mean heights (Fig. 2). Visually similar trends were observed between untrimmed and trimmed patches (growth and regrowth) of Dictyota (Fig. 2). Taller mean heights overall were seen in untrimmed patches, and shorter mean heights were observed in trimmed patches, reflecting incomplete regrowth of $\sim 1 \mathrm{~cm}$ high Dictyota of the trimmed experiment in the monthly measurement intervals.

Results from percent cover analyses were qualitatively similar to thallus height growth (Fig. 3; Table S1 in the Supplement). Percent cover analyses showed significant differences in Dictyota abundance between months (Table S1) in contrast to that observed in thallus height results (Table 2). Dictyota percent cover was not significantly affected by nutrient addition like in thallus height results (Table 2;
Table S1). There was no significant difference between uncaged-ambient plots and partially caged plots (control), resulting in minimal caging effects on Dictyota heights (1-way ANOVA, Tukey's HSD; untrimmed: $\mathrm{p}=0.985$, trimmed: $\mathrm{p}=0.994$ ) and Dictyota percent cover (1-way ANOVA, Tukey's HSD; untrimmed: $p=0.812$, trimmed: $p=0.860$ ).

\subsection{Expt 2: Effect of nutrients and herbivory on Dictyota biomass}

Both herbivore reduction and nutrient addition had significant effects on the growth of Dictyota biomass (Fig. 4a). Results from a 2-way ANOVA showed that the crossed treatments, herbivore reduction $\left(F_{1,34}=9.49, \mathrm{p}=0.006\right)$ and nutrient addition $\left(F_{1,34}=5.57, \mathrm{p}=0.024\right)$, were each significantly different with no interaction between treatment levels $\left(F_{1,34}=0.03, \mathrm{p}=0.864\right)$. Whether caged or un-

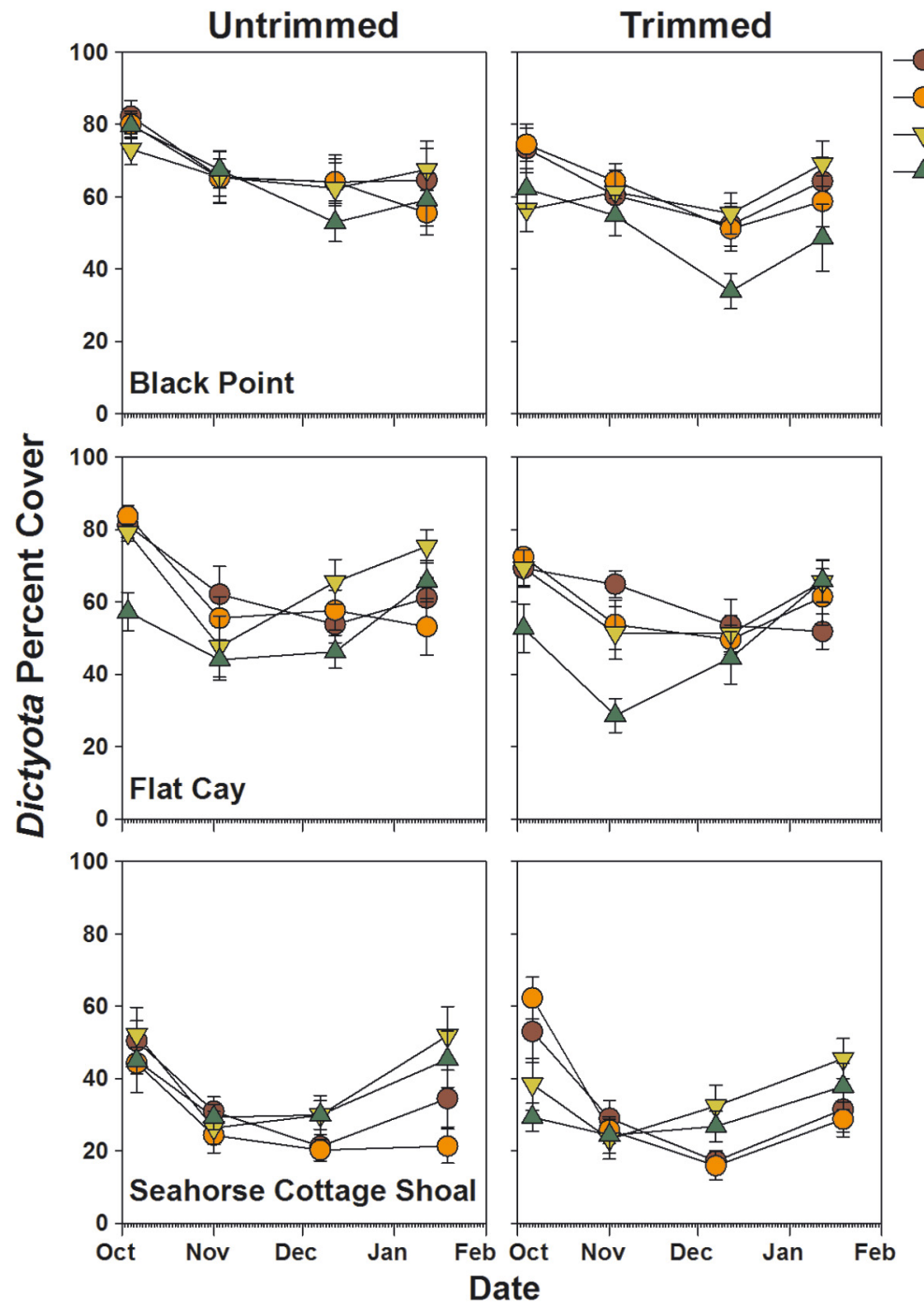

Fig. 3. Expt 1 mean Dictyota percent cover \pm SE for untrimmed and trimmed patches at 3 sites, from October 2016 to January 2017. Ten replicates of each treatment were measured at each site. Treatments as in Fig. 2 


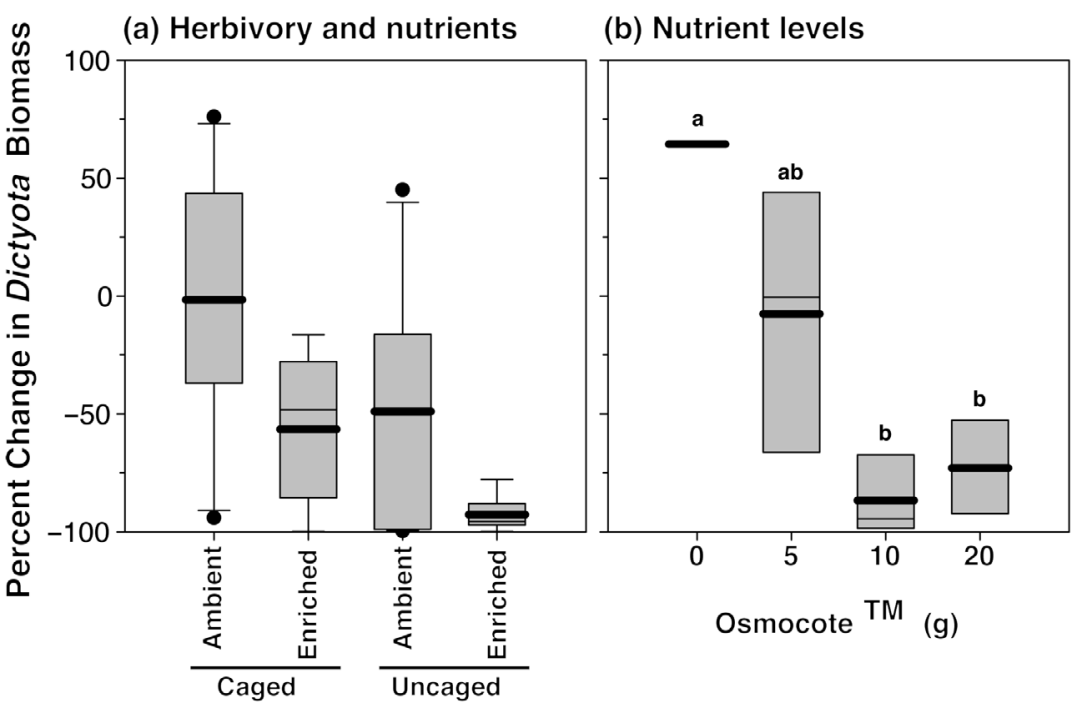

Fig. 4. Mean percent change in Dictyota biomass \pm SE over 21 d during (a) Expt 2 and (b) Expt 3. Treatments as in Fig. 2. Box plot parameters are mean (thick black line), median (thin black line), $25^{\text {th }}$ and $75^{\text {th }}$ percentiles (bottom and top of box, respectively), $10^{\text {th }}$ and $90^{\text {th }}$ percentiles (bottom and top whiskers, respectively), and values outside $10^{\text {th }}$ and $90^{\text {th }}$ percentile (dots). Panel (a) shows the results of a 2-way ANOVA indicating a significant effect of caging $(p=0.006)$ and nutrients $(p=0.024)$, separately, but no significant interaction between caging and nutrients $(p=0.863)$. In panel $(b)$, different letters indicate significant differences (post hoc test results, $\mathrm{p}<0.05$ ). Osmocote: Osmocote Smart-Release plant fertilizer addition had a significant negative effect on the average percent change in Dictyota biomass (Fig. $4 b_{;} F_{3,10}=7.753$, $\mathrm{p}=0.006$ ). A post hoc Tukey's HSD test revealed significant differences between 0 and $10 \mathrm{~g}(\mathrm{p}=0.01)$, and 0 and $20 \mathrm{~g}(\mathrm{p}=0.01)$ of Osmocote fertilizer (Fig. 4b). The addition of $5 \mathrm{~g}$ of plant fertilizer resulted in no large change in Dictyota biomass $(-7.69 \pm 29.97 \%)$. Plots treated with 10 and $20 \mathrm{~g}$ of fertilizer lost about $75 \%$ or more of their initial biomass $(-86.76 \pm 9.28$ and -73.04 $\pm 11.10 \%$, respectively). In contrast, the $0 \mathrm{~g}$ treatment resulted in growth over the same period of $3 \mathrm{wk}(+64.37 \pm$ $41.83 \%$ ). Results using plastic cages in Expt 3 also suggested that the nutrient results observed in Expts 1 and 2 were not influenced by the presence of galvanized wire mesh cages. These results helped discount any possible contamination or interaction with the metal mesh cages in Expts 1 and 2. caged, Dictyota biomass declined by about $50 \%$ over $21 \mathrm{~d}$ when enriched with plant fertilizer (Fig. 4a). Similarly, herbivory reduced Dictyota biomass by about $50 \%$ in $21 \mathrm{~d}$. The impacts of nutrients and herbivory were additive, such that there was near complete biomass loss in open and enriched plots $(-92.96 \% \pm 2.32 \mathrm{SE}$; Fig. 4a).

\subsection{Expt 3: Effect of increasing nutrients on Dictyota biomass}

The third experiment was conducted to further test the unexpected relationship between nutrient addition and negative Dictyota biomass percent change. Results from a 1-way ANOVA showed that nutrient

\subsection{Water nutrient analyses}

Nutrient analysis results from Expt 3 showed high initial and low final concentrations of nitrates + nitrites and ammonium with a significant effect of time period (initial and post-experiment) on nutrient concentration (2-way ANOVA; $F_{1,10}=28.7, \mathrm{p}=$ $0.0042)$, and no effect of fertilizer level on nutrient concentration (2-way ANOVA; $F_{3,10}=0.57, \mathrm{p}=0.44$ ). The greatest difference between the average initial and post-experiment sampling was observed in the $20 \mathrm{~g}$ treatment (Table 3). When comparing the ambient nutrient control and the $0 \mathrm{~g}$ treatment, there was no significant effect of overflow between the levels of fertilizer (1-way ANOVA, Tukey's HSD; nitrates + nitrites: $\mathrm{p}=0.99$, ammonium: $\mathrm{p}=0.94$ ).

Table 3. Average Expt 3 nutrient analysis results $(\mu \mathrm{M} \pm \mathrm{SE})$ by treatment $(0,5,10$, and $20 \mathrm{~g}$ added nutrients). Ambient control is reported without $\mathrm{SE}$ because only 1 sample was taken initially and at the end of the $21 \mathrm{~d}$ experiment

\begin{tabular}{|lcccccc|}
\hline & & $0 \mathrm{~g}$ & $5 \mathrm{~g}$ & $10 \mathrm{~g}$ & $\begin{array}{c}20 \mathrm{~g} \\
\text { Ambient } \\
\text { control }\end{array}$ \\
\hline Initial & & & & & $1.74 \pm 0.49$ & 0.93 \\
& Nitrate + Nitrite & $1.04 \pm 0.19$ & $1.03 \pm 0.01$ & $1.35 \pm 0.32$ & $1.81 \pm 0.7$ & 0.85 \\
After 21 d & Ammonia & $0.77 \pm 0.16$ & $0.73 \pm 0.02$ & $1.31 \pm 0.46$ & $0.39 \pm 0.09$ & 0.55 \\
& Nitrate + Nitrite & $0.33 \pm 0.08$ & $0.53 \pm 0.07$ & $0.36 \pm 0.08$ & $0.37 \pm 0.06$ \\
\hline
\end{tabular}




\section{DISCUSSION}

The phase shift from low to high macroalgal cover on Caribbean coral reefs was hypothesized to be driven primarily by the loss of herbivores (Hughes et al. 1999) and increase of nutrients (Lapointe 1997, 1999). Our study indicates that in the USVI, the biomass and height of Dictyota, the dominant fleshy macroalgae, are influenced primarily by the top-down effects of herbivory, whereas the bottom-up effects of nutrients are weak because the algae are likely to be nutrient replete. While most previous studies have demonstrated a positive effect (Bell 1992, Lapointe et al. 1997, Sotka \& Hay 2009) or negligible effect (Miller et al. 1999) of nutrient enrichment on Dictyota growth, this study shows an inhibition of growth in all forms measured (height, percent cover, and biomass) when enriched with nutrients (similar to McClanahan et al. $2002,2003,2004)$. In contrast to previous predictions and models (Littler \& Littler 1984, Bell 1992, Lapointe 1997), in this study Dictyota growth was not increased by nutrient enrichment regardless of concentration or herbivore reduction. Similar to our findings, Miller et al. (1999) showed that even when nutrient levels were locally elevated, macroalgal abundances were not increased in either the presence or absence of herbivores in the Florida Keys (but see Littler et al. 2006b for an alternative explanation). In addition, McClanahan et al. (2003) found that frondose brown algal cover in Belize was negatively affected by herbivory and inhibited by high nutrient levels.

Historically, fishing and disease have altered herbivorous fish and urchin communities in the USVI and the wider Caribbean, leading to declines in grazers, and subsequently greater abundances of macroalgae (Carpenter 1990, Beets \& Rogers 2000, Jackson et al. 2001, Kadison et al. 2017). Numerous experiments have shown that exclusion or removal of these herbivorous grazers results in increased macroalgal abundance on coral reefs (Lirman 2001, Williams et al. 2001, Hughes et al. 2007, Roff \& Mumby 2012). According to experiments conducted in Belize by McClanahan et al. (2003), high levels of brown algae were likely due to coral mortality and low herbivory. Our findings suggest that the high abundance of Dictyota is likely facilitated by the same factors, i.e. historic losses of coral cover and declining herbivore grazing. Although not directly tested in this study, the coral cover at sites surveyed in this study has been reduced by almost half since 1980 (Jackson et al. 2014), as coral cover now averages 15-18\% (Smith et al. 2016), and similar patterns of declining coral cover contributing to increasing macroalgal cover have been observed in other areas of the Caribbean (Williams et al. 2001, Mumby 2009, Vega Thurber et al. 2012, Burkepile et al. 2013).

Additionally, parrotfish population densities in the USVI have been low compared to other areas in the Caribbean (Jackson et al. 2014), likely due to overfishing and limited regulations. Although small amounts of herbivory on unenriched Dictyota (biomass and height) appeared to occur at all sites in Expt 1 (Fig. 2), overall herbivory did not reduce the already high Dictyota biomass. Interestingly, in this study, herbivores did not strongly target Dictyota unless the algae were enriched with nutrients. Dictyota cover in the selected Expt 1 plots was high at all sites, reaching levels of $\sim 80 \%$ cover (Fig. 3). In enriched treatments open to herbivory, a significant negative effect on Dictyota growth in all forms (height, cover, and biomass) was observed, consistent with other studies that have shown more rapid feeding by herbivorous fishes on nutrient-enriched macroalgae (Boyer et al. 2004, Fong et al. 2006, Furman \& Heck 2008, Sotka \& Hay 2009, Shantz et al. 2017). It is common for herbivores not to be able to exert top-down control over algae that are unpalatable due to chemical or physical defenses (Thacker et al. 2001); however, in our study, nutrient enrichment may have counteracted the deterrent effects of algal defenses, making them more palatable to herbivores (Cruz-Rivera \& Hay 2003).

In the USVI, the potentially inhibitive effect of nutrient addition resulted in decreased growth in all metrics measured in this study (height, percent cover, and biomass). This does not seem to have been an effect of fertilizer toxicity or competition with other algae. Osmocote Smart-Release was chosen for these experiments because it does not contain micronutrients and has been shown to stimulate macroalgal growth, including Dictyota (Zaneveld et al. 2016). In addition, Expt 2, which used plastic caging materials, showed that the metal mesh cages used in Expts 1 and 3 were not interacting with the fertilizer to cause a toxic effect. Enhanced competitive abilities of other algal taxa (e.g. Lobophora variegata) in the presence of higher nutrients was also not an explanation for inhibition of Dictyota growth in Expt 1. Dictyota was commonly epiphytic on Lobophora in our experiment, not overgrown by Lobophora, and other macroalgal species were rare in our plots. Thus, Dictyota was likely inhibited by nutrient concentrations.

Dictyota in ambient conditions may have been nutrient replete because of periodic pulses of nutrients; however, negative effects were observed when additional nutrients were added (about $75 \%$ or more of initial biomass lost; Fig. 4). Dictyota may have 
evolved to take advantage of periodic nutrient pulses for survival in low-nutrient environments like coral reefs. The inhibition of growth under higher nutrient levels in this study may be caused by an adaptation in nutrient-poor environments known as 'luxury uptake'. Luxury uptake is an absorption of nutrients, not associated with biomass production, which enables algae to rapidly exploit nutrient pulses and store them for future growth (Gerloff \& Krombholz 1966, Raven \& Taylor 2003, Reef et al. 2012). The ability to store nutrients during periodic pulses can be advantageous in an environment where nutrient availability is inconsistent (den Haan et al. 2016); however, nutrient storage has a threshold above which growth rates can be reduced (Reef et al. 2012).

Caribbean Dictyota in some locations may be inhibited by very high levels of nutrients like phosphorus and nitrogen (Miller et al. 1999, McClanahan et al. 2002, 2004, Reef et al. 2012). Inhibition of growth may occur because algae may be in a state primed for uptake during nutrient pulses and will continue to absorb nutrients even when internal levels become elevated (Fujita 1985, Fong et al. 2003, Silkin \& Chubchikova 2007, Reef et al. 2012). When algae are nutrient replete, the excess ions in the cells can lead to osmotic imbalance; water is absorbed, and cells may burst, leading to thallus breakdown (Lobban \& Harrison 1994). Indeed, this decline in health through apparent thallus breakdown was visually observed during this study in enriched treatments without herbivory. In the field, enriched thalli appeared very thin with abnormal apices and margins and had a mucilaginous texture. In a larger-scale partial reef enrichment experiment with nitrogen and phosphorus, Koop et al. (2001) did not observe a stimulation of primary production of epilithic algal communities, and only detected minor increases in larger macroalgal growth. In particular, rapid nitrogen uptake was observed in the red alga Laurencia intricata J.V. Lamouroux, 1813, consistent with the hypothesis that algae conditioned to lower concentrations of nutrients in oligotrophic conditions would show a higher capacity or adaptation for nutrient uptake during irregular pulses of nutrients (Fujita 1985). In another study, opportunistic macroalgae like Dictyota were able to acquire a large fraction of nutrients from episodic runoff events (den Haan et al. 2016). At the 3 sites in this study, the acute nutrient fluxes may be caused by human disturbance (i.e. increased runoff associated with development and land-use changes) in St. Thomas, USVI. Pollution and nutrient pulses may be particularly damaging for some macroalgae grown in chronically low nutrient environments (Lovelock et al. 2007, den Haan et al. 2016). The popular concept that a slight elevation in nutrient concentration could cause a rapid shift towards high macroalgal cover was not supported by this study and others (Miller et al.1999, McClanahan et al. 2002, 2003, 2004, Diaz-Pulido \& McCook 2003).

Additionally, results from our study suggest that herbivory, although minimal, is a driving factor of Dictyota abundance and that higher levels of herbivory may sufficiently control the abundance of Dictyota. With increased herbivore populations, Dictyota cover and coral-algal interactions will likely decrease, therefore facilitating coral recovery (Zaneveld et al. 2016). Despite herbivore communities differing greatly, protecting herbivore populations in general (especially those in areas with long histories of overfishing) by enforcing local management of sustainable fishing practices will increase the resilience of coral-dominated reefs (Lewis 1986, Burkepile \& Hay 2006, Jackson et al. 2014). Numerous studies have shown positive results for coral reef health and survival when reducing both nutrient pollution and overfishing (Mumby 2006, Hughes et al. 2007, Mumby et al. 2007, Mumby \& Steneck 2008). Increased conservation and restoration of coral reefs should also be a priority. To further protect and manage Caribbean coral reefs, the complex dynamics of the interactions between herbivorous grazers, corals, and macroalgae need to be understood.

Acknowledgements. T.N.R. thanks colleagues for valuable field and logistical support, especially R. Brewer, R. Ennis, L. Olinger, A. Durdall, E. Kadison, S. Heidmann, C. Howe, D. Lasseigne, L. Brown, A. Chaves Fonnegra, K. Ewen, V. Brandtneris, and J. Cassell. Statistical analysis assistance was provided by A. Chaves Fonnegra and S. Habtes. This study was funded by grants to T.B.S. from the USVI Department of Planning and Natural Resources and the NOAA Coral Reef Conservation Program (Territorial Coral Reef Monitoring Program; VI G007PNRT17), the Virgin Islands Experimental Program to Stimulate Competitive Research (NSF 0814417), and the NOAA Ecology of Harmful Algal Blooms Program (NA11NOS4780062). This research was partly funded by a grant awarded to A.T. from Mote Marine Laboratory's Protect Our Reefs Grants Program (POR-20144). A.T. thanks F. Paul for lab assistance. The results and opinions of this article are those of the authors and do not reflect the opinions of the funding agencies. This is contribution 238 from the Center for Marine and Environmental Studies, University of the Virgin Islands.

\section{LITERATURE CITED}

Beach K, Walters L, Borgeas H, Smith C, Coyer J, Vroom P (2003) The impact of Dictyota spp. on Halimeda populations of Conch Reef, Florida Keys. J Exp Mar Biol Ecol 297:141-159 
Beach KS, Walters LJ, Borgeas HB (2006) Irradiance and nutrient limitation of Dictyota spp. populations on Conch Reef, Florida Keys, USA. J Exp Mar Biol Ecol 329: 101-112

Beets J, Rogers C (2000) Changes in fishery resources and reef fish assemblages in a Marine Protected Area in the US Virgin Islands: the need for a no take marine reserve. Proc $9^{\text {th }}$ Int Coral Reef Symp 1:449-454

Bell PRF (1992) Eutrophication and coral reefs - some examples in the Great Barrier Reef lagoon. Water Res 26: 553-568

Boyer KE, Fong P, Armitage AR, Cohen RA (2004) Elevated nutrient content of tropical macroalgae increases rates of herbivory in coral, seagrass, and mangrove habitats. Coral Reefs 23:530-538

Brandt ME, Ruttenberg BI, Waara R, Miller J, Witcher B, Estep AJ (2012) Dynamics of an acute coral disease outbreak associated with the macroalgae Dictyota spp. Bull Mar Sci 88:1035-1050

Brock RE (1982) A critique of the visual census method for assessing coral reef fish populations. Bull Mar Sci 32: 269-276

Bruno JF, Selig ER, Casey KS, Page CA and others (2007) Thermal stress and coral cover as drivers of coral disease outbreaks. PLOS Biol 5:e124

Bruno JF, Sweatman H, Precht WF, Selig ER, Schutte VG (2009) Assessing evidence of phase shifts from coral to macroalgal dominance on coral reefs. Ecology 90: 1478-1484

Burkepile DE, Hay ME (2006) Herbivore vs. nutrient control of marine primary producers: context-dependent effects. Ecology 87:3128-3139

Burkepile DE, Allgeier JE, Shantz AA, Pritchard CE, Lemoine NP, Bhatti LH, Layman CA (2013) Nutrient supply from fishes facilitates macroalgae and suppresses corals in a Caribbean coral reef ecosystem. Sci Rep 3: 1493

Carpenter RC (1986) Partitioning herbivory and its effects on coral reef algal communities. Ecol Monogr 56: 345-363

* Carpenter RC (1990) Mass mortality of Diadema antillarum. Mar Biol 104:67-77

* Cronin G, Hay ME (1996) Effects of light and nutrient availability on the growth, secondary chemistry, and resistance to herbivory of two brown seaweeds. Oikos 77: 93-106

* Cruz-Rivera E, Hay ME (2003) Prey nutritional quality interacts with chemical defenses to affect consumer feeding and fitness. Ecol Monogr 73:483-506

* Dell CLA, Longo GO, Burkepile DE, Manfrino C (2020) Few herbivore species consume dominant macroalgae on a Caribbean coral reef. Front Mar Sci 7:676

* Den Haan J, Huisman J, Brocke HJ, Goehlich H and others (2016) Nitrogen and phosphorus uptake rates of different species from a coral reef community after a nutrient pulse. Sci Rep 6:28821

* Diaz-Pulido G, McCook LJ (2003) Relative roles of herbivory and nutrients in the recruitment of coral-reef seaweeds. Ecology 84:2026-2033

Earle SA (1972) The influence of herbivores on the marine plants of Great Lameshur Bay, St. John, Virgin Islands. In: Collette BB, Earle SA (eds) Results of the Tektite Program: ecology of coral reef fishes. Nat Hist Mus LA County Sci Bull 14:17-44

Edmunds PJ (2013) Decadal-scale changes in the commu- nity structure of coral reefs of St. John, US Virgin Islands. Mar Ecol Prog Ser 489:107-123

Edmunds PJ (2019) Three decades of degradation lead to diminished impacts of severe hurricanes on Caribbean reefs. Ecology 100:e02587

Ennis RS, Brandt ME, Grimes KR, Smith TB (2016) Coral reef health response to chronic and acute changes in water quality in St. Thomas, United States Virgin Islands. Mar Pollut Bull 111:418-427

Fong P, Paul VJ (2011) Coral reef algae. In: Dubinsky Z, Stambler N (eds) Coral reefs: an ecosystem in transition. Springer, Dordrecht, p 241-272

Fong P, Boyer KE, Kamer K, Boyle KA (2003) Influence of initial tissue nutrient status of tropical marine algae on response to nitrogen and phosphorus additions. Mar Ecol Prog Ser 262:111-123

FFong P, Smith TB, Wartian MJ (2006) Epiphytic cyanobacteria maintain shifts to macroalgal dominance on coral reefs following ENSO disturbance. Ecology 87: 1162-1168

Fredericks X, Kranenburg CJ, Nagle DB (2015) EAARL-B submerged topography_-Saint Thomas, US Virgin Islands, 2014. US Geological Survey data release. https: //doi.org/10.5066/F7G15XXG

Friedlander A, Beets J (2008) Temporal trends in reef fish assemblages inside Virgin Islands National Park and around St. John, US Virgin Islands, 1988-2006. NOAA Tech Memo NOS NCCOS 70. NOAA, Silver Spring, MD

Fujita RM (1985) The role of nitrogen status in regulating transient ammonium uptake and nitrogen storage by macroalgae. J Exp Mar Biol Ecol 92:283-301

F Furman BT, Heck KL Jr (2008) Effects of nutrient enrichment and grazers on coral reefs: an experimental assessment. Mar Ecol Prog Ser 363:89-101

Furnas M, Mitchell A, Skuza M, Brodie J (2005) In the other $90 \%$ : phytoplankton responses to enhanced nutrient availability in the Great Barrier Reef Lagoon. Mar Pollut Bull 51:253-265

*Gardner TA, Côte IM, Gill JA, Grant A, Watkinson AR (2005) Hurricanes and Caribbean coral reefs: impacts, recovery patterns, and role in long-term decline. Ecology 86:174-184

Gerloff GC, Krombholz PH (1966) Tissue analysis as a measure of nutrient availability for the growth of angiosperm aquatic plants. Limnol Oceanogr 11:529-537

Gladfelter WB, Gladfelter EH, Monahan RK, Ogden JC, Dill RD (1977) Environmental studies of Buck Island Reef National Monument, St. Croix, USVI. US Dept Interior, National Park Service Report, Washington, DC

*Hay ME (1997) The ecology and evolution of seaweedherbivore interactions on coral reefs. Coral Reefs 16: S67-S76

*Hay ME, Duffy JE, Pfister CA (1987) Chemical defense against different marine herbivores: Are amphipods insect equivalents? Ecology 68:1567-1580

*Herren LW, Walters LJ, Beach KS (2006) Fragment generation, survival, and attachment of Dictyota spp. at Conch Reef in the Florida Keys, USA. Coral Reefs 25: 287-295

*Hoegh-Guldberg O, Mumby PJ, Hooten AJ, Steneck RS and others (2007) Coral reefs under rapid climate change and ocean acidification. Science 318:1737-1742

*Hughes TP (1994) Catastrophes, phase shifts and largescale degradation of a Caribbean coral reef. Science 265: 1547-1551 
Hughes T, Szmant AM, Steneck R, Carpenter R, Miller S (1999) Algal blooms on coral reefs: What are the causes? Limnol Oceanogr 44:1583-1586

* Hughes TP, Rodrigues MJ, Bellwood DR, Ceccarelli D and others (2007) Phase shifts, herbivory, and the resilience of coral reefs to climate change. Curr Biol 17:360-365

Jackson JBC, Kirby MX, Berger WH, Bjorndal KA and others (2001) Historical overfishing and the recent collapse of coastal ecosystems. Science 293:629-637

Jackson JBC, Donovan M, Cramer K, Lam V (eds) (2014) Status and trends of Caribbean coral reefs 1970-2012. Global Coral Reef Monitoring Network, International Union for the Conservation of Nature Global Marine and Polar Program, Washington, DC

Kadison E, Brandt M, Nemeth R, Martens J, Blondeau J, Smith T (2017) Abundance of commercially important reef fish indicates different levels of over-exploitation across shelves of the US Virgin Islands. PLOS ONE 12: e0180063

King RJ, Farrant PA (1987) The phenology of the Dictyotales (Phaeophyceae) at a sheltered locality in Sydney Harbour, New South Wales, Australia. Bot Mar 30:341-350

Kohler K, Gill SM (2006) Coral Point Count with Excel extensions (CPCe): a visual basic program for the determination of coral and substrate coverage using random point count methodology. Comput Geosci 32: 1259-1269

Koop K, Booth D, Broadbent A, Brodie J and others (2001) ENCORE: The effect of nutrient enrichment on coral reefs. Synthesis of results and conclusions. Mar Pollut Bull 42:91-120

Lapointe BE (1997) Nutrient thresholds for bottom-up control of macroalgal blooms on coral reefs in Jamaica and southeast Florida. Limnol Oceanogr 42:1119-1131

Lapointe BE (1999) Simultaneous top-down and bottom-up forces control macroalgal blooms on coral reefs (Reply to the comment by Hughes et al.). Limnol Oceanogr 44: 1586-1592

Lapointe BE, Littler MM, Littler DS (1997) Macroalgal overgrowth of fringing coral reefs at Discovery Bay, Jamaica: bottom-up versus top-down control. Proc $8^{\text {th }}$ Int Coral Reef Symp 1:927-932

Lessios HA (1988) Mass mortality of Diadema antillarum in the Caribbean: What have we learned? Annu Rev Ecol Syst 19:371-393

Lewis S (1986) The role of herbivorous fishes in the organization of a Caribbean reef. Ecol Monogr 56:183-200

Liddell WD, Ohlhorst SL (1986) Changes in benthic community composition following the mass mortality of Diadema at Jamaica. J Exp Mar Biol Ecol 95:271-278

Kirman D (2001) Competition between macroalgae and corals: effects of herbivore exclusion and increased algal biomass on coral survivorship and growth. Coral Reefs 19:392-399

Littler DS, Littler MM (2000) Caribbean reef plants. Offshore Graphics, Washington, DC

Littler MM, Littler DS (1984) Relationships between macroalgal functional form groups and substrata stability in a subtropical rocky-intertidal system. J Exp Mar Biol Ecol 74:13-34

Littler MM, Littler DS, Brooks BL (2006a) Harmful algae on tropical coral reefs: bottom-up eutrophication and topdown herbivory. Harmful Algae 5:565-585

Kittler MM, Littler DS, Brooks BL, Lapointe BE (2006b) Nutrient manipulation methods for coral reef studies: a critical review and experimental field data. J Exp Mar Biol Ecol 336:242-253

Lobban CS, Harrison PJ (1994) Seaweed ecology and physiology. Cambridge University Press, New York, NY

Lovelock CE, Feller IC, Ball MC, Ellis J, Sorrell B (2007) Testing the growth rate vs. geochemical hypothesis for latitudinal variation in plant nutrients. Ecol Lett 10: 1154-1163

Mathieson AC, Fralick RA, Burns R, Flahive W (1971) Comparative studies of subtidal vegetation in the Virgin Islands and the New England coastlines. In: Miller JW, VanDerwalker RA, Waller RA (eds) Tektite II: scientists in the sea. US Department of the Interior, Washington, DC, p 106-117

*McClanahan TR, Muthiga NA (1998) An ecological shift in a remote coral atoll of Belize over 25 years. Environ Conserv 25:122-130

McClanahan TR, Cokos BA, Sala E (2002) Algal growth and species composition under experimental control of herbivory, phosphorus and coral abundance in Glovers Reef, Belize. Mar Pollut Bull 44:441-451

*McClanahan TR, Sala E, Stickels PA, Cokos BA, Baker AC, Starger CJ, Jones SH IV (2003) Interaction between nutrients and herbivory in controlling algal communities and coral condition on Glover's Reef, Belize. Mar Ecol Prog Ser 261:135-147

* McClanahan TR, Sala E, Mumby PJ, Jones S (2004) Phosphorus and nitrogen enrichment do not enhance brown frondose 'macroalgae.'. Mar Pollut Bull 48:196-199

* McCook LJ (1999) Macroalgae, nutrients and phase shifts on coral reefs: scientific issues and management consequences for the Great Barrier Reef. Coral Reefs 18: 357-367

*McCook L, Jompa J, Diaz-Pulido G (2001) Competition between corals and algae on coral reefs: a review of evidence and mechanisms. Coral Reefs 19:400-417

* Miller MW, Hay ME, Miller SL, Malone D, Sotka EE, Szmant AM (1999) Effects of nutrients versus herbivores on reef algae: a new method for manipulating nutrients on coral reefs. Limnol Oceanogr 44:1847-1861

Kumby PJ (2006) The impact of exploiting grazers (Scaridae) on the dynamics of Caribbean coral reefs. Ecol Appl 16:747-769

Mumby PJ (2009) Phase shifts and the stability of macroalgal communities on Caribbean coral reefs. Coral Reefs 28:761-773

Mumby PJ, Steneck RS (2008) Coral reef management and conservation in light of rapidly evolving ecological paradigms. Trends Ecol Evol 23:555-563

* Mumby PJ, Hastings A, Edwards HJ (2007) Thresholds and the resilience of Caribbean coral reefs. Nature 450: 98-101

* Murugan A, Begum MS, Ramasamy MS, Raja P (2012) Antifouling and antipredatory activity of natural products of the seaweeds Dictyota dichotoma and Chaetomorpha linoides. Nat Prod Res 26:975-978

Olsen K, Ritson-Williams R, Paul VJ, Ross C (2014) Combined effects of macroalgal presence and elevated temperature on the early life-history stages of a common Caribbean coral. Mar Ecol Prog Ser 509:181-191

* Paul VJ, Kuffner IB, Walters LJ, Ritson-Williams R, Beach KS, Becerro MA (2011) Chemically mediated interactions between macroalgae Dictyota spp. and multiple life-history stages of the coral Porites astreoides. Mar Ecol Prog Ser 426:161-170 
R Core Team (2013) R: a language and environment for statistical computing. R Foundation for Statistical Computing, Vienna

Rasher DB, Hay ME (2010) Chemically rich seaweeds poison corals when not controlled by herbivores. Proc Natl Acad Sci USA 107:9683-9688

Rasher DB, Stout EP, Engel S, Kubanek J, Hay ME (2011) Macroalgal terpenes function as allelopathic agents against reef corals. Proc Natl Acad Sci USA 108: 17726-17731

Raven JA, Taylor R (2003) Macroalgal growth in nutrientenriched estuaries: a biogeochemical and evolutionary perspective. Water Air Soil Pollut 3:7-26

Reef R, Pandolfi JM, Lovelock CE (2012) The effect of nutrient enrichment on the growth, nucleic acid concentrations, and elemental stoichiometry of coral reef macroalgae. Ecol Evol 2:1985-1995

Renken H, Mumby PJ, Matsikis I, Edwards HJ (2010) Effects of physical environmental conditions on the patch dynamics of Dictyota pulchella and Lobophora variegata on Caribbean coral reefs. Mar Ecol Prog Ser 403:63-74

Roff G, Mumby PJ (2012) Global disparity in the resilience of coral reefs. Trends Ecol Evol 27:404-413

Rogers CS, Miller J (2001) Coral bleaching, hurricane damage, and benthic cover on coral reefs in St. John, US Virgin Islands: a comparison of surveys with the chain transect method and videography. Bull Mar Sci 69:459-470

Rogers CS, Miller J (2006) Permanent 'phase shifts' or reversible declines in coral cover? Lack of recovery of two coral reefs in St. John, US Virgin Islands. Mar Ecol Prog Ser 306:103-114

Shantz AA, Ladd MC, Burkepile DE (2017) Algal nitrogen and phosphorus content drive inter- and intraspecific differences in herbivore grazing on a Caribbean reef. J Exp Mar Biol Ecol 497:164-171

Shantz AA, Ladd MC, Burkepile DE (2020) Overfishing and the ecological impacts of extirpating large parrotfish from Caribbean coral reefs. Ecol Monogr 90:e01403

Silkin VA, Chubchikova IN (2007) Kinetics of uptake of phosphates and nitrates by marine multicellular algae Gelidium latifolium (Grev.) Born. et Thur. Biol Bull Russ Acad Sci 34:156-162

Smith TB, Nemeth RS, Blondeau J, Calnan JM, Kadison E, Herzlieb S (2008) Assessing coral reef health across onshore to offshore stress gradients in the US Virgin Islands. Mar Pollut Bull 56:1983-1991

Smith TB, Ennis R, Kadison E, Nemeth RS, Henderson LM (2016) The United States Virgin Islands Territorial Coral Reef Monitoring Program. 2016 Annual Report. University of the Virgin Islands, USVI

Editorial responsibility: Peter Edmunds,

Northridge, California, USA

Reviewed by: M. W. Miller and 1 anonymous referee
Sotka EE, Hay ME (2009) Effects of herbivores, nutrient enrichment, and their interactions on macroalgal proliferation and coral growth. Coral Reefs 28:555-568

Thacker RW, Ginsburg DW, Paul VJ (2001) Effects of herbivore exclusion and nutrient enrichment on coral reef macroalgae and cyanobacteria. Coral Reefs 19:318-329

* Tronholm A, Sansón M, Afonso-Carrillo J, De Clerck O (2008) Distinctive morphological features, life-cycle phases and seasonal variations in subtropical populations of Dictyota dichotoma (Dictyotales, Phaeophyceae). Bot Mar 51:132-144

* Tronholm A, Sansón M, Afonso-Carrillo J, Verbruggen H, De Clerck O (2010a) Niche partitioning and the coexistence of two cryptic Dictyota (Dictyotales, Phaeophyceae) species from the Canary Islands. J Phycol 46:1075-1087

Tronholm A, Steen F, Tyberghein L, Leliaert F, Verbruggen H, Ribera Siguan MA, De Clerck O (2010b) Species delimitation, taxonomy, and biogeography of Dictyota in Europe (Dictyotales, Phaeophyceae). J Phycol 46: 1301-1321

* Tronholm A, Afonso-Carrillo J, Sansón M, Leliaert F, Fernández-García C, De Clerck O (2013) Taxonomy of the Dictyota ciliolata-crenulata complex (Dictyotales, Phaeophyceae). Phycologia 52:171-181

* Vega Thurber R, Burkepile DE, Correa AM, Thurber AR and others (2012) Macroalgae decrease growth and alter microbial community structure of the reef-building coral, Porites astreoides. PLOS ONE 7:e44246

Vroom PS, Walters LJ, Beach KS, Coyer JA, Smith J, Abgrall MJ, Byron D (2005) Hurricane-induced propagation and rapid growth of the weedy brown alga Dictyota in the Florida Keys. Fla Sci 68:161-174

Williams ID, Polunin NVC, Hendrick VJ (2001) Limits to grazing by herbivorous fishes and the impact of low coral cover on macroalgal abundance on a coral reef in Belize. Mar Ecol Prog Ser 222:187-196

Wilson N, Parrish CE, Battista T, Wright CW and others (2019) Mapping seafloor relative reflectance and assessing coral reef morphology with EAARL-B topobathymetric lidar waveforms. Estuaries Coasts doi:10.1007/s 12237-019-00652-9

Womersley HBS (1987) The marine benthic flora of Southern Australia, Part II. South Australian Government Printing Division, Adelaide

*Worm B, Reusch TBH, Lotze HK (2000) In situ nutrient enrichment: methods for marine benthic ecology. Int Rev Hydrobiol 85:359-375

Z Zaneveld JR, Burkepile DE, Shantz AA, Pritchard CE and others (2016) Overfishing and nutrient pollution interact with temperature to disrupt coral reefs down to microbial scales. Nat Commun 7:11833

Submitted: September 15, 2020

Accepted: June 8, 2021

Proofs received from author(s): July 30, 2021 